This item was submitted to Loughborough's Research Repository by the author.

Items in Figshare are protected by copyright, with all rights reserved, unless otherwise indicated.

\title{
Energy policy under austerity localism: what role for local authorities?
}

PLEASE CITE THE PUBLISHED VERSION

http://dx.doi.org/10.1080/03003930.2017.1359164

PUBLISHER

(c) Taylor \& Francis

VERSION

AM (Accepted Manuscript)

\section{PUBLISHER STATEMENT}

This work is made available according to the conditions of the Creative Commons Attribution-NonCommercialNoDerivatives 4.0 International (CC BY-NC-ND 4.0) licence. Full details of this licence are available at: https://creativecommons.org/licenses/by-nc-nd/4.0/

\section{LICENCE}

CC BY-NC-ND 4.0

\section{REPOSITORY RECORD}

Morris, Jonathan, John Harrison, Andrea Genovese, Liam Goucher, and S.C. Lenny Koh. 2019. "Energy Policy Under Austerity Localism: What Role for Local Authorities?”. figshare. https://hdl.handle.net/2134/25570. 


\section{Energy policy under austerity localism: What role for Local Authorities?}

Jonathan Morris ${ }^{{ }^{*}}$, John Harrison ${ }^{b}$, Andrea Genovese ${ }^{a}$, Liam Goucher ${ }^{a}$, SCL Koh ${ }^{a}$

${ }^{a}$ Management School, University of Sheffield, Sheffield, United Kingdom, S10 2TN

${ }^{b}$ School of Social, Political and Geographical Sciences, Loughborough University, Loughborough, United Kingdom, LE11 3TU

*Corresponding Author: Email: j.c.morris@sheffield.ac.uk

To cite:

Morris J, Harrison J, Genovese A, Goucher L and Koh SCL 2017 Energy policy under austerity localism: what role for local authorities? Local Government Studies 


\section{Energy policy under austerity localism: What role for Local Authorities?}

In the United Kingdom, Local Authorities have been placed at the forefront of domestic energy reduction strategies as the responsible actors for coordinating policy in this sector. Yet, there has been little research regarding the role of Local Authorities in this policy agenda, and their abilities to bring together stakeholders in the successful design and implementation of strategies to reduce energy demands. The paper aims to fill this gap by highlighting the relevance and importance of the energy policy sphere to local government studies, building on the idea of resilient Local Authorities within the context of tensions between the localism agenda and the actual implementation of energy efficiency polices. This is achieved through multiple rounds of semi-structured interviews with Local Authority officers. Our findings reveal that Local Authorities operating under a localism agenda, lack the freedoms and resources from Central Government to meet the needs of multiple stakeholders, resorting to short-term policies.

Keywords: localism, austerity, energy policy, local authorities

\section{Introduction}

Despite the United Kingdom being one of the most centralized states in Western Europe (Wollmann 2004), successive UK Governments of different political persuasions have passionately claimed to be 'localist'. In 2000, Tony Blair declared how the “[Labour] government's progressive programme of constitutional reform is now moving us from a centralised Britain, where power flowed top-down, to a devolved and plural state" (Blair 2000, 1). Meanwhile a decade later, the Conservative-led Government of David Cameron introduced the 2011 Localism Act with the following statement:

Trying to improve people's lives by imposing decisions, setting targets and demanding an inspection from Whitehall simply doesn't work. It creates bureaucracy. It leaves no room for adaptation to reflect local circumstances or 
innovation to deliver services more effectively and at lower costs (Department of Communities and Local Government (DCLG 2011).

In the intervening years, countless research articles have been published on localism, both in UK and internationally (Smith and Wistrich 2016; Lowndes and Gardner 2016; Doig 2017). Yet our starting point is a policy sphere - energy - which has arguably been, hitherto, a blind spot in local government studies ${ }^{1}$. We find this surprising because against an international backdrop of carbon reduction strategies and climate change targets, energy policy is an example of an increasingly localised agenda. Promoting interventions at the local level to reduce carbon emissions are seen as integral to the promotion of a 'decentralised energy revolution' to overcome the 'one size-fits-all' approaches commonly associated with National Government control of policy (DECC 2010; Brown, Cloke, and Harrison 2015). This supports the idea that successful bottom-up policies developed at the local level can feed-up to the national scale to meet Central Government targets and move away from the 'one-size-fits-all' policies imposed by Central Government (Schreurs 2008; Carney and Shackley 2009; Keirstead and Schulz 2010; DCLG 2011). Against this backdrop local organizations especially Local Authorities (LAs) - are seen as important actors due to the connections and trust that have within their community groups (CCC 2012). This is certainly the case in the UK where LAs have been placed at the forefront of administering domestic energy policy schemes, in particular for the domestic sector which accounts for $27 \%$ of the UK's national energy consumption (HM Government 2008; DECC 2016). Our argument in this paper while the Localism Act granted LAs a 'general power of competence' that enabled/ them, for the first time, to design any activity that they consider to be in the interest of their locality' (HM Government 2011; Ferry and Eckersley 2015), this has not been accompanied by the necessary transfer of funds required to implement such activities (Lowndes and Gardner, 2016).

Promoting and implementing energy efficiency (EE) schemes is an important policy activity for LAs; such schemes can have the benefits of: (i) reducing energy

\footnotetext{
${ }^{1}$ A search of Web of Science reveals that since the formation of Tony Blair's Labour Government in 1997, of the 662 articles (1200 if you include review essays, editorials and book reviews) published in Local Government Studies only 9 have 'energy' as a topic, with only 2 containing 'energy' in their title (Price 2004; Krøtel 2015).
} 
consumption and carbon emissions; (ii) overcoming challenges associated with living in poor quality housing and cold, damp conditions, including mental health issues, increased cardiovascular health problems, and excess winter mortality (Powells 2009; CCC 2012; Jenkins 2010; Scott, Jones, and Webb 2014; Hannon and Bolton 2015); and (iii) potentially stimulate economic development through investment in skills training and local SMEs (CCC 2012; Genovese, Koh, and Acquaye 2013; Killip 2013). Previous government policy has focused on local EE policies as a mechanism to achieve national carbon emission reductions, yet on the ground emphasis has often been placed by LAs on reducing fuel poverty. Previous research has revealed that "these aims may be related but are not as synonymous as sometimes claimed" (Pearce 2013, 216). There is also a question over the extent to which LAs are able to reduce carbon emissions, particularly given the lack of control over the 'levers' for carbon emission reduction strategies (AEA Technology 2008, 36). Localism, if accompanied by adequate resources provided to LAs, could therefore help realise not only benefits towards meeting UK energy and climate change targets, but also contribute to local economic development and improved health outcomes.

This research is especially timely because LAs have been given this role during a time of 'political austerity', which has seen their budgets cut year-on-year since 2010, and ongoing uncertainty over the future of local government funding - a situation exacerbated by the UK public voting to leave the European Union in the June 2016 referendum. To put this into context, local regeneration funding in England from the European Union is worth $f 5$ billion between 2014 and 2020 (Local Government Association 2016) and it is currently unclear if this funding will be transferred to the UK Government and maintained for LAs to access, or if it will be reduced or abolished. Additionally there are implications regarding EU regulation on council services relating to the environment and energy, as well as procurement frameworks which could, theoretically be repealed by the UK parliament (Local Government Association 2016), as well as the cessation of informal lobbying activities between local governments and the European commission that bypasses the Central (National) government that has been effective in developing regional policy and the direction of structural funding (Travers 2016). This political uncertainty makes it more, not less, important to consider the scripted role for LAs in the implementation of energy policies under 
conditions of austerity. The uncertainty that LAs face requires resilience building in these organizations, through adapting and transforming in the face of changes in legislation, regulation, and financial settlements (Fitzgerald and Lupton 2015). Initially used in ecological contexts, resilience refers to the ability of a system to absorb disturbance and still retain its basic function and structure (Folke et al. 2010; Shaw and Theobald 2011). Shaw (2012) recognises four features of resilient LAs: innovation, managing risk, strategic leadership, and enhancing the involvement of civil society. It is these facets of resilience that are examined further in this paper.

We aim to highlight the relevance and importance of developments in the energy policy sphere to local government studies and the idea of resilient LAs within the context of tensions between the localism agenda, and the actual implementation of EE policy. To do this, our paper emerges from research which has examined the capacities (the theoretical possibility to implement EE policies), and capabilities (the actual ability, backed up by resources, to implement such policies) of LAs in the UK to intervene in local energy policy and fulfil the scripted role assigned to them by Central Government. To do this we conducted semi-structured interviews with representatives of 12 LAs with responsibilities for EE and climate change. Firstly, we do this by identifying the tensions between moves to empower LA and community groups on the one hand, and the reductions in funding on the other, highlighting the apparent contradictions between the financial and political settlements for LAs. Secondly, the study evaluates the practices of LAs in implementing EE policies in their communities, identifying and analysing the relationships with service providers, community groups, and the instability caused by imposed top-down schemes from Central Government. Thirdly, the paper demonstrates how localised activities can help realise the aims of localism and energy efficiency policies given the necessary resources

\section{Literature Review}

\section{Austerity Localism in the United Kingdom}

According to The Institute for Fiscal Studies the period 2010-2015 saw the Department for Communities and Local Government (DCLG) take a funding cut equivalent to $23.4 \%$ 
per person (Innes and Tetlow 2015), significantly reducing the financial base for LA expenditure (Lowndes and Pratchett 2012; Asenova, Bailey, and McCann 2015). This has given rise to austerity localism, characterised as a transfer of responsibility from the state (national) to the community (local), but, crucially, without the equivalent transfer of resource, power, or authority (Davoudi and Madanipour 2013; Bradley 2014). Austerity localism is therefore seen as a "political strategy that delegates risk and responsibility, and accountability from central government onto new subjects local government, and private sector and local community organisations" (Williams, Goodwin, and Cloke 2014), which critics refer to as decentralising 'super-austerity' (Lowndes and Gardner 2016). This is not, however, unique to the UK. Austerity policies are now a defining feature across many European - and other non-European countries, with similar dynamics resulting in conflict as, on the one hand, decentralization increases local government responsibilities while, on the other hand, austerity sees central government cutting funding to local government (see for instance: Donald et al. 2014). This suggests remarkable inconsistency (at a continental level) between decentralization policies and austerity measures (Hlepas 2016). What marks the UK out for special attention is that, in comparison to many other (European) nations, local government is under greater central government control (Clarke and Cochrane 2013)'.

Within this context, Featherstone et al. (2012) note that "the default actors who are empowered by emerging forms of localism are likely to be those with the resources, expertise and social capital to become involved in the provision of services and facilities"; areas lacking these kinds of resources are vulnerable due to poor local economic conditions that limit the scope for an expanded private sector to compensate for the curtailment of public services (Deas and Doyle 2013). This gives rise to a distinctive geography of austerity in which different localities are affected to a greater or lesser extent depending on the level of cuts, ability to raise additional funds, and resilience (Hamnett 2014).

There is a need for LAs to exhibit resilience to changing regulatory environments and continued cuts to resources and finances. The resilient Local 
Authority framework presented by Shaw (2012) highlights how LAs can respond to funding cuts and institutional shifts by identifying opportunities to innovate, managing risk, exhibiting leadership, and promoting civic engagement. In theory, the Localism which arrived following the abolishment of institutional arrangements associated with the previous Labour Government's (2005-2010) 'regional project' (Roodbol-Mekkes and van den Brink 2015) offers an opportunity for LAs to strengthen their civic engagement, take on greater leadership, and identify innovative and new solutions to local issues, and 'bounce forward' into a more effective organisation (Shaw 2012; Fitzgerald and Lupton 2015). The Local Area Agreements (LAA) in place between 2008 and 2012 (DCLG 2009) saw LAs assessed against 35 indicators from a series of national indicators (NI). NI186 (reduction in per capita CO2 emissions in LA boundaries) had relevance for providing formal guidance from the central government for LAs to reduce carbon emissions from within their boundaries (Eadson 2008; DCLG 2009; W. Pearce 2014) but its subsequent removal has removed formal accountability and focusing mechanisms for LAs. Despite the opportunities for greater tailored, innovative, and community driven responses to environmental challenges, the imposition of austerity and the dismantling of frameworks created an area of tension between centralised resource provision and local responsibilities (Fitzgerald and Lupton 2015).

\section{Domestic Energy Efficiency: Austerity and Localism in Practice}

The pursuit of reducing energy consumption via EE policies is becoming an important challenge for governments around the world in response to the 'energy trilemma' of anthropogenic climate change, energy security, and rising energy prices (Hannon and Bolton 2015). Since 2002 the implementation of EE policy and greening domestic buildings has evolved over three distinct phases; the period from 2002 to 2008 placed obligations on energy suppliers to fund EE programmes through the Energy Efficiency Commitment (EEC) (DTI 2003), replaced by the Carbon Emissions Reduction Target (CERT), leading to supplier obligations to $£ 1.6 \mathrm{bn}$ per year for EE projects (Rosenow, Platt, and Flanagan 2013; Mallaburn and Eyre 2014). In 2009 the Community Energy Saving Programme (CESP) was launched to explicitly tackle those households in the 
bottom $10 \%$ of lower super output areas (LSOA) according to income deprivation (HM Government 2009; Rosenow, Platt, and Flanagan 2013).

Following the UK's 2010 General Election, the new administration terminated the CERT and CESP schemes in 2012, replacing them with the Energy Company Obligation (ECO) and Green Deal schemes. ECO extended the qualifying criteria of CESP to incorporate the bottom 15\% of LSOAs by income deprivation, funded by contributions from energy companies (DECC 2011a). The Green Deal provided loans to cover the upfront costs for householders for EE measures against expected bills reductions (DECC 2011b; HM Government 2011). The Green Deal Finance Fund was discontinued in July 2015, with just 10,000 houses receiving Green Deal interventions (HM Government 2015).

Under localism strategies there remains the desire for LAs to play an active role in provision of energy policy (Bale et al. 2012), for example the Green Deal and ECO schemes included provisions for LAs to identify and nudge individuals (residents and landlords) towards the uptake of these schemes (DECC 2011a, [b] 2011; Marchand, Koh, and Morris 2015). This process requires strong civic engagement because there is often a resistance from the general population towards 'green' initiatives, particularly if there is a need for a financial contribution in return for interventions, despite the possibility of EE measures to save money and/or to improve the thermal comfort of the home (Marchand, Koh, and Morris 2015). The Green Deal was criticised for creating 'disproportionate savings so that lower income and vulnerable households who do not heat their homes sufficiently may not experience the savings of those who can' (Reid and Houston 2013, 3) and added to the tensions between LA desire to promote social policies such as fuel poverty (Bale et al. 2012) and Central Government expectations to reduce $\mathrm{CO}_{2}$ emissions (W. Pearce 2014).

Practical realisations of these schemes can be achieved through market-ready technologies promoting domestic interventions (such as cavity wall insulation, loft insulation, hot water tank insulation, double glazing, and replacement boilers) (Firth and Lomas 2009) have the potential to meet 'public good' objectives such as reducing fuel poverty (Hannon and Bolton 2015) stimulate economic development through 
contracting locally based firms (Killip 2013). The initial stated aims of the localism act, particularly the need for 'adaption to reflect local circumstances' opens up a potential role for LAs in tailoring and directing interventions to areas and individuals most in need, giving greater control of the 'levers' for delivering carbon emission reduction through EE improvements, whilst the austerity agenda highlights a second aspect of the localism act, the need to 'deliver services more effectively and at lower costs' (DCLG 2011) (DCLG, 2011). Delivering these schemes requires greater organizational resilience in LAs (John 2014) and the ability to respond to funding cuts. This said, whilst the development of innovation, risk management, leadership and civic engagement characteristics in LAs (Shaw 2012) can help negate the financial shock of austerity, there is a limit to how far LAs can 'bounce back' or evolve under continued austerity (Fitzgerald and Lupton 2015).

\section{LAs as Management Organizations}

The rise of 'new public management' across North America and Europe has placed an emphasis on making the public sector more 'business like' (O'Flynn 2007), with Local Government in effect becoming 'managers', whose performance is made by its stakeholders, e.g. those benefiting from service provision, other citizens, regulatory authorities, and Central Government. The accountability of LAs to stakeholders draws on European and US planning debates of the 1970s (Healey 1998), where political activity requires the management and satisfaction of stakeholder demands and opinions. The UK's Local Government Association (Local Government Association 2011, 5) expressly states that relationship of the LA with its stakeholders is "critical to successful policy making and delivery". Given the diversity of views amongst stakeholders, LAs can be seen as managing trade-offs and developing outcomes from these measures (Greenwood 2012). Localism has the potential to further empower groups, and at the same time austerity is reducing resources for LAs to put in place appropriate interventions and not simply designing policies that appease those with the loudest voices.

In addition to stakeholder management, the shift towards managerialism in LAs in the UK has seen an alignment of objectives towards a focus on measurable 
outcomes such as reducing carbon emissions, as opposed to evaluating the links between environmental, economic, and social benefits from EE policies. The Labour Government of 2007-2010 placed emphasis on the 'efficiency' of public service provision driven by target setting in contrast to traditional goals of equity, democracy, deliberation, and social justice (W. Pearce 2013; Clifford 2016). We argue that in EE policy, the localism agenda combined with austerity policies potentially reduces LAs to the role of 'enablers' of national EE policies. However borrowing from management perspectives, the unique characteristics of LAs as focal organizations for communities can help build organizational resilience despite ongoing financial constraints, and the capacities and capabilities that LAs possess that are not easily imitated or substitutable by external organizations has maintained the ability for them to manage diverse stakeholder interests and to deliver (or commission) a wide range of both statutory and discretionary services (Gardner 2017). This research attempts to bridge the gap that exists between research focused on the types of energy efficiency interventions and schemes that LAs are expected to play a role in the organization and implementation, the drive at a national level to devolve responsibilities to LAs under localism whilst cutting resources under austerity, and the increasing managerialisation of Local Government in the United Kingdom.

\section{Methods and Data}

To understand the planning and monitoring strategies undertaken by LAs in EE strategies under localism and austerity, semi-structured interviews were conducted with 12 LA representatives across a range of different political, economic, and social settings. These interviews took place between March 2011 and November 2013. This period saw a shifting emphasis in the role of LAs as the previous Local Area Agreement Framework was dismantled, the Localism Bill and a national focus on austerity measures became prevalent, and EE policies of the Labour Government were replaced by the Coalition Government's Green Deal and ECO schemes. It is during this time where resilience building activities within LAs were expected to become more visible. These interviews used an exploratory, interpretivist approach to gain insights into the capacities and capabilities of LAs during this transitional period, and link to concepts of 
resilience, localism and austerity with particular regards to resource capacities, and the ability to manage stakeholder demands and responsibilities.

\section{Participants}

Table 1 details the surveyed LAs, detailing the type of area (rural and urban classifications from the Office of National Statistics (ONS 2009) and the prevailing political alignment of the council (Local Government Association 2015). Interviewees were recruited using purposive snowball sampling technique following initial consultation with a regional LA energy body who served as a gatekeeper. Each respondent was asked to nominate representatives from LAs holding similar positions, through networks operating across county councils, city networks, and regional authorities. Snowball sampling overcame the concerns of relying on a narrow, geographically defined sample of respondents from the gatekeeper's own network and ensured that participants sampled were relevant to the research (Brammer and Walker 2011; Hannon and Bolton 2015; Cunningham et al. 2016). Whilst snowball sampling has downsides regarding representativeness across the general population (both nationally and internationally), this method was appropriate for utilising the connections between people employed in similar job positions across different organisations and ensure those with knowledge on the frontline are consulted (Hannon and Bolton 2015) to advance the notion of the resilient LAs in the face of austerity and localism. Participants were representatives working in areas including: climate change, energy, housing, sustainability and environmental policy. 24 Authority representatives were contacted, of which 12 consented to participate in the first round of interviews, and 5 agreed to participate in further engagements.

\section{***Insert Table 1 Here***}

\section{Phase 1- Semi-Structured Interviews (March - October 2011)}

The first phase of interviews were conducted with all 12 participants in the study, and focused around themes of i) rationale for engaging in residential energy reduction and efficiency projects; ii) realising the benefits to the local area of energy reduction (focusing especially on aspects beyond energy saving and carbon emission reduction); 
iii) central government policies; iv) the role of LAs in delivering central government policies; v) the resource requirements to produce effective EE strategies. Interviews lasted approximately 1 hour and were fully transcribed and coded using a qualitativeinterpretivist approach. The main codes were chosen deductively based on these themes: discussing the drivers for implementing EE policies, the priorities of achieving climate change targets against alleviating fuel poverty, the data collected to do so, the resources available to authorities to develop and implement schemes, an evaluation of nationally produced data, their perceptions of future policy changes, and the scope for collaboration with other LAs. Within each code, sub-codes were inductively created as they emerged from the data. Analysis then followed and anonymised quotations are used here to highlight key points of concern expressed.

\section{Phase 2 - Follow up Consultations (April-May 2012 and October 2013)}

A second round of engagement with LAs took place in April and May 2012 with a subset of 5 LAs who responded to requests for further engagement. These consultations were oriented around data requirements and resource capabilities required for LAs, and the potential to act on such information. The consultation period followed the formal implementation of the Green Deal and ECO schemes and LAs facilitated the understanding the unfolding experiences of changing government policies and how LAs adapted to these changes (Pallett and Chilvers 2013). A final round of consultations took place in the following year and focused on identifying best-practices in implementing policies with two exemplar councils who had run successful schemes. In this round of interviews, two private sector companies administering local EE policies were consulted to provide additional context for the study and offer alternative viewpoints from the private sector. The interviews examined the extent to which networks of organisations are participating in planning processes under localism, and the ability for LAs to collaborate and survive under austerity. 


\section{The Role of Local Authorities? A view from the field}

Consultation with LAs revealed that it is often central government targets and legislation which drives action at a local level, with locally developed planning approaches often side-lined in favour of 'off the self' approaches, particularly given resource cuts as a result of austerity policies. Whilst this is presented as a tension between local and central governments, the idea of 'resilient LAs' identifies a series of opportunities, as well as conflicts, for LAs to pursue new strategies under the new localism settlement.

\section{Opportunities to Innovate}

An area to innovate emerged from the conflicts between, on the one hand LAs wishing to design, develop, and implement policies that benefit their communities economically and socially, and on the other a national focus on macro-level outcomes such as reductions in carbon emission and energy consumption. The development of an 'aspirational gap' was repeatedly emphasised from LAs, whereby council's longterm objectives to reduce fuel poverty and improve the quality of the housing within their boundaries were often side-lined in order to focus on short-term measures to reduce energy and carbon, and motivation for policy action is driven by 'primarily government targets, but there is a political desire too' (LA2) and less of a focus on energy reductions but 'more focus on fuel poor and the vulnerable' (LA10).

Innovative solutions could overcome what LA1 highlighted as the 'slight irony' of applying EE policies to reduce fuel poverty, where $\mathrm{CO}_{2}$ reduction focused policy would 'probably drive carbon up rather than down'. LA3 stated that part of the problem is that the policies 'confuse fuel poverty with carbon saving. It's a big overlap but not necessarily the same thing', and these tensions highlight how despite current Central Government policy emphasising carbon emissions reveals the divergent objectives between Local and National Government. Innovative approaches would help LAs to overcome and the lack of capacities and capabilities to engage in joined up policy-making, for example the way in which ECO schemes are utilised. LA7 highlighted that the use of income deprivation for a national scheme went against the Council's aim to target multiple deprivation, the use of which could improve quality of life 
outcomes. Innovative strategies would need to overcome the 'political element' (LA2), where local political lobbying for specific areas to receive measures that they do not need can arise in instances where qualification criteria are not so narrowly defined. LA2 highlights how "councils need to be targeting the right properties" to ensure 'in need' areas are not overlooked. This is a problem with localised policy implementation with a lack of resources, as well as changing schemes from above adding to the resource requirements of LAs in responding to new directives. On the ground, these stories give further weight to suggestions that LAs are merely implementing directives from above, reducing innovation in order to manage risk.

\section{Risk Management}

Further examples of risk management at LA level can be seen in the implementation of the UK Government's flagship energy reduction scheme, the Green Deal. The perceived 'exclusion' of low income households from the Green Deal (Reid and Houston, 2013) was a recurring theme in interviews, with LA5 stating that 'if you're not adequately heating your house now, you'll only get pay-back if you continue to not adequately heat your home'. Further concerns of the Green Deal arose due to the unpredictability of occupant behaviour (Dowson et al. 2012) and the use of modelling to predict energy reductions from installing insulation and technical measures into inefficient housing (Lomas 2009). Managing the affordability risk of the Green Deal was emphasised by LA1:

\footnotetext{
Why take out or put money into something like a loan when it's hard enough to engage people when you do it for free, put it all in, clean up the mess, take away all the rubbish. Why would anyone want to put $f 6000$ onto their electricity meters to do it? Seems like a bit flawed thinking, or flawed expectations.
}

These criticisms extended to the private sector, with one contractor firm representative, stated: “On a practical level the Green Deal doesn't work because you can get cheaper credit from a commercial loan or from re-mortgaging". This suggests that the levers to encourage a market-based solution are simply not adequate for performing necessary infrastructure improvements to the housing stock and provides 
a risk to both the Authority promoting the scheme (in terms of reputation) and to householders applying for Green Deal funding. Although critical of the scheme, the LA1 representative acknowledged that, "we're a public organisation, they are the rules and we'll try and make it work", showing LAs as acting in a role that attempts to do what is best for the local community. This links to the idea of LAs as leadership organizations.

\section{Support for Low Income and Vulnerable Households: Leadership}

Engagement with LA representatives revealed consistent desires to provide support for low income and vulnerable households. Schemes such as CESP and ECO appear to tap into the strengths and objectives held by LAs for engaging in community-based EE schemes, however the introduction of ECO meant England no longer had a centrally funded fuel poverty strategy and ECO funding arrangements described as giving an opportunity for "energy companies to meet their targets without stimulating a demand for products that would lead to reductions in overall energy demand" (LA12). There is a consensus amongst the LAs surveyed that expecting energy companies to fund schemes that would lead to reductions in household energy demand made little sense and funding cuts led to reservations regarding the direction energy policy was heading for local councils, with LA11 stating:

\footnotetext{
The key problem I see for the future is a public attitude towards spending public money, which is, we try not to subsidise, everything is partnerships and private investment and private finance and that's a Government culture...which is discounted way off to the future into tomorrow, means that people don't want to commit resources and finance.
}

Finance emerged as an important issue for LAs in implementing their EE schemes, testing their resilience in the face of nationally driven policies and requiring leadership to address the imbalance between resources and responsibilities. LAs are organizations with the ability to draw a number of stakeholders together to develop innovative and engaged policies, and LAs are required to take the lead on managing public-private partnerships to ensure finances are directed to maximise community benefits. LA12 suggested that the balance between public and private involvement in 
the ECO scheme is regressive and that financing the ECO scheme should be from general taxation. This proposed transfer of funding does raise political issues. A Sustainability and Regeneration Business Manager at an EE firm questioned whether a scheme funded out of general taxation and subsidising construction products would contravene the European Union's 'double subsidy' rule. Not only this, but reverting to exchequer funding for EE schemes would represent a U-turn in the ideology of successive UK Governments and would not appear to be a realistic option in the longrun. LA12 stated that any taxation-based scheme would have to be ring-fenced otherwise funding "would be spent on priority areas such as education", assuming that LAs were distributed the money in the first place. Given that the Localism Bill gives a greater voice to community groups, LAs may struggle to gain acceptance for spending public money and promoting these schemes in a manner that satisfies the wider community. Convincing the wider community requires not only strong leadership but also strong civic engagement.

\section{Civic Engagement}

Despite the extent of continued cuts to LA budgets they remain organisations of 'trust' (DECC 2012; G. Pearce and Cooper 2013). This 'trust' between LAs and their communities and residents was emphasised by LA10, who claimed that "there's the whole trust issue with sellers, people with big business as part of the Green Deal and I think that's why Councils will be part of the mechanism to deliver it". This was common view held by both private sector companies working on LA directed projects, who agreed that their businesses required LAs to initially gain acceptance from the community for their services. The shift towards localism and the set-up of schemes that require greater private sector involvement, with LAs viewed as 'management organisations' or 'partnership facilitators'. This generates conflict between different community groups within the area, the elected representatives, and the desires of the Council. Therefore the challenge for LAs in sustaining partnerships also requires gaining and maintaining acceptance from the 'end users' of EE policies. 
Whilst LAs believe that they have the key skills and expertise to serve this role, the continual need to build new partnerships and adjust to changing rules, regulations and focus weakens the ability for them to engage with their communities and deliver a clear message as to why EE schemes are important. With cuts to budgets and difficulty in engaging widespread community support there are real challenges in sustaining EE and fuel poverty policies, as highlighted by LA6:

One of the key issues for us is because so many areas are being changed all at once, so many policies pulled and policies changing across the board it's much harder to sustain those partnerships. Voluntary sector/community sectors are losing workers. Funding is finishing and there's no successor. There's greatly reduced funding for new projects and that really has had a severe impact on my line of work.

This highlights that whilst changing legislation can be a source of frustration it does also offer opportunities to identify new methods of designing and monitoring schemes. A key response is the 'hope' that policies and directives will settle down, and enable long-term planning of EE schemes.

\section{Resilience through Long-Term Integration and Planning: A Case Study of Success}

LAs drawing upon innovation, leadership, and civic engagement capabilities whilst minimising risk to public investment can produce well designed, long term plans to reduce energy consumption and improve local communities. The example of a successful scheme run in social housing presented by a Managing Director at an EE Service Firm highlighted how leaning on LA direction to provide schemes to entire wards can galvanise those that would not have previously considered taking out EE measures, in particular affluent home owners. This would enable the Authority to focus on the priority group, but also to entice the 'able to pays' to invest in measures that would ultimately lead to reductions in energy demand. Joined up planning could produce a range of benefits to society from EE measures, such as health benefits, civic pride from residents as a result of the Council investing in their local area, and improving the aesthetics of local neighbourhoods (Jenkins 2010; Scott, Jones, and 
Webb 2014).

A second strategy for utilising energy reduction policy funding to generate a range of social successes grew from an initial regeneration scheme providing boundary wall replacement and driveway maintenance in 2003. The scheme overcome of the barriers of success (trust, resources, and continuity) through developing long-term relationships (10 years) between community groups and local contractor firms, enabling the Authority to take advantage of Government initiatives and Energy Company funding and tailor these finances towards devising and implementing wide scale housing regeneration schemes. The scheme, which initially aimed to renovate 60 homes in total, but the success of the scheme spread through word of mouth, leading to work being carried out to more than 750 properties. From an investment of $f 5.8 \mathrm{~m}$, the results of this scheme were reported as an annual fuel saving of $£ 354,700$, and saving 121,121 tons of carbon a year. Demonstrating success of policies can be achieved through non-quantitative measures, for example a local resident testimonial, who stated that: "For the first time in four years we can heat the whole of the house instead of cramming into one room. The children can do their homework in their own bedrooms and concentrate on their studies". This type of data can justify to their communities' energy schemes that go beyond a narrow focus on energy reduction and carbon saving, and justify the need to spend public money to achieve their aims. This would enable LAs to engage closer with their community's needs, and help demonstrate success for their projects and can show the benefits of public sector investment in these types of projects. However changes to funding schemes had led to funding being returned, despite the fact that people in the area 'had heard about the scheme and were interested' due to an organizational decision to ensure the provision of fair opportunities. Even in an example of a successful case study, the experience of this council highlights that the constraints on LAs in the UK in terms of funding, resources, and changes to Central Government priorities can present additional challenges on the abilities for LAs to build resilience capacities in response to stakeholder demands. 


\section{Conclusions}

This research highlights how local authorities are dealing with filling the role at the forefront of energy efficiency policy, whilst experiencing funding cuts and substantial responsibility changes as a result of austerity and localism policies. Despite these pressures, there is a strong rationale for placing LAs in a role that is at the forefront of devising and implementing domestic sector energy efficiency schemes due to the unique ability of LAs to consult with the wide range of stakeholders from the local community as well as the main funders and beneficiaries of such schemes, and their role as a trusted organisation within local community groups. Austerity localism simultaneously empowers and weakens the LA position as an organisation of policy implementers and gives rise to the need for a 'resilient' LA; that is one which is able to manage risk, exhibit leadership, innovate, and promote civic engagement.

The findings from the planning stages of EE policies adds to contemporary research regarding the current devolution settlement in the United Kingdom, and emphasises the imbalance between the responsibilities and demands placed on LAs. From a localism agenda - LAs feel they lack resources, due to austerity, to implement policies that would best serve their communities, which is compounded by Central Government accountability targets aimed at tackling national and global climate chainge priorities that restrict the types of activities that LAs can engage in to be considered a 'success', and is the root of this tension between the local and the national. The ability for LAs to actively engage their communities and deliver carbon reductions, and energy-based 'public goods' is constrained by the local austerity regime. It remains to be seen what effect the UK leaving the European Union will have on resource provision to LAs. Rebalancing the responsibilities and resources handed down from Central Government across a range of different policy objectives when setting local development policies can help LAs maintain capacity to promote local economic development and establish long term strategic local partnerships. However continued austerity may weaken LAs' abilities to devise and implement policies, and to manage the demands of numerous stakeholders, particularly if the localism agenda is being used as a way to devolve risks and responsibilities to the local level of 
governance.

Whilst the UK is a specific case, given that how centralised it is compared to other European - and non-European - countries, the pressures facing UK local authorities are not unique. The conflict between decentralisation and austerity may manifest itself in a more extreme fashion in the UK, but this, alongside greater private sector involvement and responsibility for local action to meet national climate change objectives are now firmly established as common trends. For this reason, further research that allows comparison of the governance structures in operation in different countries would provide for a deeper understanding of local actors are managing such pressures in different contexts, and crucially, what can be learnt from successes and failures across different geographical and political regions. 


\section{References}

AEA Technology. 2008. "Analysis to Support Climate Change for Local Authorities". London: Department for Environent, Food, and Rural Affairs.

Asenova, Darinka, Stephen Bailey, and Claire McCann. 2015. “Managing Municipal Austerity: Mitigation of Social Risks." Local Government Studies 41 (1): 1-19. doi:10.1080/03003930.2014.919268.

Bale, Catherine SE, Timothy J Foxon, Matthew J Hannon, and William F Gale. 2012. "Strategic Energy Planning within Local Authorities in the UK: A Study of the City of Leeds." Energy Policy 48: 242-51.

Blair, T. 2000. "Speech on Britishness The Labour Party." Milbank, London.

Bradley, Quintin. 2014. "Bringing Democracy Back Home: Community Localism and the Domestication of Political Space." Environment and Planning D: Society and Space 32 (4): 642-57.

Brammer, Stephen, and Helen Walker. 2011. "Sustainable Procurement in the Public Sector: An International Comparative Study." International Journal of Operations \& Production Management 31 (4): 452-76.

Brown, Ed, Jon Cloke, and John Harrison. 2015. "Governance, Decentralisation and Energy: A Critical Review of the Key Issues." READ Working Paper 1.

Carney, Sebastian, and Simon Shackley. 2009. "The Greenhouse Gas Regional Inventory Project (GRIP): Designing and Employing a Regional Greenhouse Gas Measurement Tool for Stakeholder Use." Energy Policy 37 (11): 4293-4302. doi:10.1016/j.enpol.2009.05.028.

CCC. 2012. "How Local Authorities Can Reduce Emissions and Manage Climate Risk". London: Committee on Climate Change.

Clarke, Nick, and Allan Cochrane. 2013. "Geographies and Politics of Localism: The Localism of the United Kingdom's Coalition Government." Political Geography 34: 10-23.

Clifford, Ben. 2016. "'Clock-Watching and Box-Ticking': British Local Authority Planners, Professionalism and Performance Targets." Planning Practice \& Research 31 (4): 383-401. doi:10.1080/02697459.2016.1178038. 
Cunningham, Rebecca, Christopher Cvitanovic, Thomas Measham, Brent Jacobs, AnneMaree Dowd, and Ben Harman. 2016. “Engaging Communities in Climate Adaptation: The Potential of Social Networks." Climate Policy 16 (7): 894-908. doi:10.1080/14693062.2015.1052955.

Davoudi, Simin, and Ali Madanipour. 2013. "Localism and Neo-Liberal Governmentalit." Town Planning Review 84 (5): 551-62.

DCLG. 2009. "Local Area Agreements (LAAs) and Local Economic Development". London: Department for Communities and Local Government. http://eprints.mdx.ac.uk/4161/1/Local_area_agreements_and_local_economic _development.pdf.

- - . 2011. "A Plain English Guide to the Localism Bill: Update". London: Crown Copyright.

http://www.gov.uk/government/uploads/ystem/uploads/attachment_data/file /5958/1923416.pdf.

Deas, lain, and Jennifer Doyle. 2013. "Building Community Capacity under 'austerity Urbanism': Stimulating, Supporting and Maintaining Resident Engagement in Neighbourhood Regeneration in Manchester." Journal of Urban Regeneration \& Renewal 6 (4): 365-80.

DECC. 2010. “Warm Homes, Greener Homes: A Strategy for Household Energy Management". London: Crown Copyright.

- - . 2011a. "Extra Help Where Is Needed: A New Energy Company Obligation". London: Crown Copyright.

http//www.gov.uk/government/uploads/system/uploads/attachment_data/fil e/48086/1732-extra-help-where-it-is-needed-a-new-energy-compan.pdf.

- - . 2011b. "Green-Deal Summary Proposals". London: Crown Copyright. http//www.gov.uk/government/uploads/system/uploads/attachment_data/fil e\%2F47978/1010-green-deal-summary-proposals.pdf.

- - . 2012. "Guidance to English Energy Conservation Authorities: Issued Pursuant to the Home Energy Conservation Act 1995". 12D/296. London: Crown Copyright.

- - . 2016. "Energy: Chapter 1, Digest of United Kingdom Energy Statistics (DUKES)." Total Energy Statistics Digest of UK Energy Statistics (DUKES). 
Doig, Alan. 2017. “New Development: Local Government Ethics in England: How Is Local Ownership Working?" Public Money \& Management 37 (1): 63-68. doi:10.1080/09540962.2016.1233785.

Donald, Betsy, Amy Glasmeier, Mia Gray, and Linda Lobao. 2014. "Austerity in the City: Economic Crisis and Urban Service Decline?" Cambridge Journal of Regions, Economy and Society 7 (1): 3-15. doi:10.1093/cjres/rst040.

Dowson, Mark, Adam Poole, David Harrison, and Gideon Susman. 2012. "Domestic UK Retrofit Challenge: Barriers, Incentives and Current Performance Leading into the Green Deal." Energy Policy 50: 294-305.

DTI. 2003. "Our Energy Future: Creating a Low Carbon Economy". London: The Stationary Office.

Eadson, Will. 2008. “People, Place \& Policy Online: Issue 3: Climate Change Mitigation in Local Area Agreements: An Enforced Lack of Ambition?" November 12. http://extra.shu.ac.uk/ppp-online/issue_3_121108/article_4_full.html.

Featherstone, David, Anthony Ince, Danny Mackinnon, Kendra Strauss, and Andrew Cumbers. 2012. "Progressive Localism and the Construction of Political Alternatives." Transactions of the Institute of British Geographers 37 (2): 17782.

Ferry, Laurence, and Peter Eckersley. 2015. "Budgeting and Governing for Deficit Reduction in the UK Public Sector: Act Three 'accountability and Audit Arrangements.'" Public Money \& Management 35 (3): 203-10.

Firth, S, and KJ Lomas. 2009. "Investigating CO2 Emission Reduction in Existing Urban Housing Using a Community Energy Model." In Building Simulation. Fitzgerald, Amanda, and Ruth Lupton. 2015. "The Limits to Resilience? The Impact of Local Government Spending Cuts in London." Local Government Studies 41 (4): $582-600$.

Folke, Carl, Stephen R Carpenter, Brian Walker, Marten Scheffer, Terry Chapin, and Johan Rockström. 2010. “Resilience Thinking: Integrating Resilience, Adaptability and Transformability." Ecology and Society 15 (4): 20.

Gardner, Alison. 2017. "Big Change, Little Change? Punctuation, Increments and MultiLayer Institutional Change for English Local Authorities under Austerity." Local Government Studies 43 (2): 150-69. doi:10.1080/03003930.2016.1276451. 
Genovese, Andrea, SC Lenny Koh, and Adolf Acquaye. 2013. “Energy Efficiency Retrofitting Services Supply Chains: Evidence about Stakeholders and Configurations from the Yorskhire and Humber Region Case." International Journal of Production Economics 144 (1): 20-43.

Greenwood, Dan. 2012. "The Challenge of Policy Coordination for Sustainable Sociotechnical Transitions: The Case of the Zero-Carbon Homes Agenda in England." Environment and Planning C: Government and Policy 30 (1): 162-79. Hamnett, Chris. 2014. "Shrinking the Welfare State: The Structure, Geography and Impact of British Government Benefit Cuts." Transactions of the Institute of British Geographers 39 (4): 490-503.

Hannon, Matthew J, and Ronan Bolton. 2015. "UK Local Authority Engagement with the Energy Service Company (ESCo) Model: Key Characteristics, Benefits, Limitations and Considerations." Energy Policy 78: 198-212.

Healey, Patsy. 1998. "Building Institutional Capacity through Collaborative Approaches to Urban Planning." Environment and Planning a 30 (9): 1531-46.

Hlepas, Nikolaos-Komninos. 2016. "Is It the Twilight of Decentralization? Testing the Limits of Functional Reforms in the Era of Austerity." International Review of Administrative Sciences 82 (2): 273-90. doi:10.1177/0020852315581994.

HM Government. 2008. "Climate Change Act Chapter 27". The Stationary Office. http://www.legislation.gov.uk/ukpga/2008/27/pdfs/ukpga_20080027_en.pdf.

- - . 2009. "Community Energy Saving Programme (CESP): Consultation Document". London: The Stationary Office.

- - 2011. "Energy Act 2011". London: The Stationary Office. http://www.legislation.gov.uk/ukpga/2011/16/resources.

- - . 2015. "Press Release: Green Deal Finance Company Funding to End." https://www.gov.uk/government/news/green-deal-finance-company-fundingto-end.

Innes, David, and Gemma Tetlow. 2015. “Central Cuts, Local Decision-Making: Changes in Local Government Spending and Revenues in England, 2009-10 to 2014-15." IFS Briefing Note BN166. Institute for Fiscal Studies.

Jenkins, DP. 2010. "The Value of Retrofitting Carbon-Saving Measures into Fuel Poor Social Housing." Energy Policy 38 (2): 832-39. 
John, Peter. 2014. "The Great Survivor: The Persistence and Resilience of English Local Government." Local Government Studies 40 (5): 687-704. doi:10.1080/03003930.2014.891984.

Keirstead, James, and Niels B. Schulz. 2010. “London and beyond: Taking a Closer Look at Urban Energy Policy." Energy Policy, Special Section on Carbon Emissions and Carbon Management in Cities with Regular Papers, 38 (9): 4870-79. doi:10.1016/j.enpol.2009.07.025.

Killip, Gavin. 2013. "Transition Management Using a Market Transformation Approach: Lessons for Theory, Research, and Practice from the Case of Low-Carbon Housing Refurbishment in the UK." Environment and Planning C: Government and Policy 31 (5): 876-92.

Krøtel, Sarah ML. 2015. “Contracting for Energy Efficiency: The Diffusion of Novel Contracting Practices at Local Government Level." Local Government Studies 41 (5): 794-813.

Local Government Association. 2011. "The LGA Quick Guide to Local Government." http://local.gov.uk/c/document_library/get_file?uuid=a5b2c920-8f40-eae9852-8b983724f5b\&groupld=10180.

- - . 2015. "Majority Party for All Councils at 07 May 2015."

- - . 2016. "Local Government Association Briefing: Leaving the European Union." http://www.local.gov.uk/documents/10180/5533246/30062016+LGA+briefing +-+exiting+from+the+EU-WEB.pdf/09692d16-67a9-4957-b9ec-39f024250c30.

Lomas, Kevin J. 2009. “Decarbonizing National Housing Stocks: Strategies, Barriers and Measurement." Building Research \& Information 37 (2): 187-91.

Lowndes, Vivien, and Alison Gardner. 2016. “Local Governance under the Conservatives: Super-Austerity, Devolution and the 'smarter State.'" Local Government Studies, 1-19.

Lowndes, Vivien, and Lawrence Pratchett. 2012. "Local Governance under the Coalition Government: Austerity, Localism and the 'Big Society.'” Local Government Studies 38 (1): 21-40.

Mallaburn, Peter S, and Nick Eyre. 2014. "Lessons from Energy Efficiency Policy and Programmesin the UK from 1973 to 2013." Energy Efficiency 7 (1): 23-41. 
Marchand, Robert D, SC Lenny Koh, and Jonathan C Morris. 2015. “Delivering Energy Efficiency and Carbon Reduction Schemes in England: Lessons from Green Deal Pioneer Places." Energy Policy 84: 96-106.

O’Flynn, Janine. 2007. “From New Public Management to Public Value: Paradigmatic Change and Managerial Implications." Australian Journal of Public Administration 66 (3): 353-66. doi:10.1111/j.1467-8500.2007.00545.x.

ONS. 2009. "Rural/urban Local Authority (LA) Classification (England)." http://webarchive.nationalarchives.gov.uk/20160105160709/http://www.ons. gov.uk/ons/guide-method/geography/products/area-classifications/ruralurban-definition-and-la/rural-urban-local-authority--la--classification--england/index.html.

Pallett, Helen, and Jason Chilvers. 2013. "A Decade of Learning about Publics, Participation, and Climate Change: Institutionalising Reflexivity?" Environment and Planning A 45 (5): 1162-83.

Pearce, Graham, and Stuart Cooper. 2013. "The Challenges of Delivering Climate Change Policy at the Sub-National Level." Town Planning Review 84 (4): 44165.

Pearce, W. 2013. "The Meanings of Climate Change Policy: Implementing Carbon Reduction in the East Midlands". PhD, Nottingham. etheses.nottingham.ac.uk/3680/.

- - . 2014. "Scientific Data and Its Limits: Rethinking the Use of Evidence in Local Climate Change Policy." Evidence \& Policy: A Journal of Research, Debate and Practice 10 (2): 187-203. doi:10.1332/174426514X13990326347801.

Powells, Gareth Douglas. 2009. “Complexity, Entanglement, and Overflow in the New Carbon Economy: The Case of the UK's Energy Efficiency Commitment." Environment and Planning. A 41 (10): 2342.

Price, Trevor. 2004. "Is Renewable Energy Planning Blowing in the Wind?" Local Government Studies 30 (2): 266-75.

Reid, Louise Anne, and Donald Houston. 2013. “Low Carbon Housing: A 'Green’Wolf in Sheep's Clothing?" Housing Studies 28 (1): 1-9. 
Roodbol-Mekkes, Petra H, and Adri van den Brink. 2015. "Rescaling Spatial Planning: Spatial Planning Reforms in Denmark, England, and the Netherlands." Environment and Planning C: Government and Policy 33 (1): 184-98.

Rosenow, Jan, Reg Platt, and Brooke Flanagan. 2013. "Fuel Poverty and Energy Efficiency obligations-A Critical Assessment of the Supplier Obligation in the UK." Energy Policy 62: 1194-1203.

Schreurs, Miranda A. 2008. "From the Bottom Up: Local and Subnational Climate Change Politics." The Journal of Environment \& Development 17 (4): 343-55. doi:10.1177/1070496508326432.

Scott, Fiona L, Christopher R Jones, and Thomas L Webb. 2014. "What Do People Living in Deprived Communities in the UK Think about Household Energy Efficiency Interventions?" Energy Policy 66: 335-49.

Shaw, Keith. 2012. "The Rise of the Resilient Local Authority?" Local Government Studies 38 (3): 281-300.

Shaw, Keith, and Kate Theobald. 2011. "Resilient Local Government and Climate Change Interventions in the UK." Local Environment 16 (1): 1-15. doi:10.1080/13549839.2010.544296.

Smith, David M., and Enid Wistrich. 2016. Devolution and Localism in England. Routledge.

Travers, Tony. 2016. "Implications of a Brexit for UK National Governance and Local Government: Report of the Hearing Held on 13th April, 2016."

Williams, Andrew, Mark Goodwin, and Paul Cloke. 2014. "Neoliberalism, Big Society, and Progressive Localism." Environment and Planning A 46 (12): 2798-2815.

Wollmann, Hellmut. 2004. "Local Government Reforms in Great Britain, Sweden, Germany and France: Between Multi-Function and Single-Purpose Organisations." Local Government Studies 30 (4): 639-65. doi:10.1080/0300393042000318030. 
i To put the UK imbalance between central and local government in context, the latest OECD Revenue Statistics reveal that (devolved) local and state/regional tax-raising in the UK is $1.6 \%$ of GDP (compared to the $8.8 \%$ OECD average) while federal or central government tax-raising stands at $24.9 \%$ (compared to the $20.4 \%$ OECD average). Source: https://stats.oecd.org/Index.aspx?DataSetCode=REV . 